Bajopas Volume 10 Number 2 December, 2017

http://dx.doi.org/10.4314/bajopas.v10i2.25

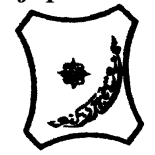

Bayero Journal of Pure and Applied Sciences, 10(2): 146 - 151

Received: June, 2017

Accepted: November, 2017

ISSN $2006-6996$

\title{
MALARIA OCCURRENCE AND AWARENESS AMONGST ALMAJIRAI IN SOME SELECTED TRADITIONAL QUR'ANIC CENTRES OF KANO MUNICIPAL AND GWALE LOCAL GOVERNMENT AREAS OF KANO STATE
}

\author{
${ }^{1}$ Amina Babayo Hamma* and ${ }^{2}$ Zainab Tukur \\ ${ }^{1,2}$ Department of Biological Science, Bayero University, Kano. \\ *Correspondence author: aminababayo@gmail.com
}

\begin{abstract}
Malaria an infectious mosquito-borne disease of humans remains a great cause of poverty in Africa. This study aimed at assessing the occurrence of malaria Parasitaemia and anaemia among different aged group Almajirai in selected traditional Qur'anic centres residing in Municipal and Gwale L.G.As of Kano State. Total of 454 Blood samples from Almajirai of Municipal and Gwale Local Government Areas of Kano Municipal were examined for malaria parasitaemia (MP) using method for microscopic diagnosis of malaria parasites. Anaemia was diagnosed as mild and severe when Packed Cells Volumes (PCV) was below 33\% and 25\% respectively. Result of the blood (MP) from the two (2) local governments showed that only Plasmodium falciparum species, was encountered. The total positive sample recorded were 162 (35.7\%). The highest occurrence $47.4 \%$ was recorded within 9-13 age group and the least 1.8\% was recorded within 24-28 age groups in Gwale. Statistically no significant difference (P-value $>0.05$ ) was observed among the various age groups of the two local governments. Anaemia was compared between malaria parasitized and nonparasitized subject, anaemia was observed to be associated with the severity of malaria infection. Almajirai should be given free malaria treatment in all government hospital so that those who could not go to hospital due to treatment cost will avail themselves of such opportunities received quality medical care. There is need to introduce appropriate intervention strategies against malaria and its vector, as well increase distribution of Insecticide Treated Nets to Almajirai.
\end{abstract}

Key words: Malaria, Almajirai, Tsangayu, Municipal, Gwale

\section{INTRODUCTION}

Tsangaya is a traditional Qur'anic centre where parents enrolled their young children so that they could get introduced to the teaching of Islam at an early age (Bashir, 2014). Almajiri refers to young pupils who purse Quranic education under the Almajiranci system. It is important to recalled the term Almajiranci is derived from the Arabic word "Almuhajirun" the migrants. It refers to a traditional system in Hausa land whereby people move from place to place for the sole purpose of studying the Holy Qur'an (Sunusi, 2005).

The Almajirai encounter a lot of difficulties and hardships during their period of scholarships. They normally sleep in an open space or in crowded rooms, at times people temporarily allowed them to sleep in the passage of their houses, most of them lived in areas where disease transmitting mosquitoes are present, Almajirai cope with severe weather conditions, these makes them prone to a lot of health hazards (Fadlullah, 2003). The attitude of Almajirai exposed them to various kinds of mosquitoes breeding sites and easy contact with mosquitoes. These conditions would result in contracting malaria, because all it takes is a single bite from an infected female Anopheles mosquitoes to get the infection (CDC, 2015).

This study aimed at assessing the occurrence of malaria Parasitaemia and anaemia among different aged group Almajirai in selected traditional Qur'anic centres residing in Gwale and Kano Municipal L.G.As of Kano State.

\section{HYPOTHESES}

There is no malaria amongst Almajirai in selected Tsangayu of Gwale and Kano Municipal Local Government Areas.

There is no variation in mean of malaria Parasitaemia and anaemia between different age group Almajirai of Gwale and Kano Municipal Local Government Areas.

\section{MATERIALS AND METHODS \\ Study Area}

The principal inhabitants of the community are Hausa people as in most part of Northern Nigeria. The houses were predominantly made up of mud and the community were characterised by overcrowding, inconsistent Municipal water supply, stagnant water bodies of Gwale and poor sanitation. Observation based findings showed major streets; several open spaces and even water ways are used as refuse dump sites. Majority of this are left unattended for long period of time, the wastes are blown around by wind or rainstorm making the environment dirty, sometimes the waste block drainage channels. The heaps of the solid waste serve as good hideouts for dangerous reptiles, rodents and insects. 


\section{Study Design}

The study population were Almajirai of aged 9-28 years. Stratified random sampling technique was employed. Five different Tsangayu were randomly selected within the two Local Government Areas of the study. This was done by assigning a unique number to Tsangayu, The numbers were placed in a bowl and thoroughly mixed, then blind-folded researcher selected the number, Tsangaya having the selected number was included in the sample. For the Almajirai, there were grouped in strata according to their age group, this was done to ensure different aged $A /$ majirai were included in the sample since is a homogeneous population, followed by random selection of individuals from each strata. The minimum sample size was calculated to be 226.7 using the formula according to Fishers et al., 1996 as shown below

$$
N=\frac{Z^{2} p q}{D^{2}}
$$

Where

$\mathrm{N}$ : $\quad$ Desired sampled size

Z: $\quad$ Standard normal deviate at $95 \%$ confidence level usually set at 1.96

P: $\quad$ Prevalence of $9-35$ Years found to have malaria parasite in previous study as $17.7 \%(0.177)$

Q: $\quad 1-p=1.0-0.177=0.82$

D: Degree of precision or acceptable error margin (56 or 0.05 ).

$$
N=\frac{(1.96)^{2} \times 0.177 \times 0.82}{(0.05)^{2}}
$$

$\mathrm{N}=226.7$

\section{Ethical Consideration}

Ethical approvals for the study were obtained from Kano State Hospital Management Board, Qur'anic and Islamiyya Schools Management Board as well as verbal consent seeks from each Almajiri participating in the study.

\section{Blood Sample Collection}

About $2 \mathrm{ml}$ of venous blood sample were obtained from a peripheral vein into an Ethylene Diamine Tetraacetic Acid (EDTA) bottle for the preparation of thick and thin blood film as well as pack cell volume (Cheesbrought, 2009).

\section{Pack Cell Volume Estimation}

Heparinized capillary tubes were used to obtained blood from blood sample already collected; one end of the capillary tube was sealed with plasticin gum. Several samples were assembled in the centrifuge (Heamatocrit Machine) and spinned at 5000 revolution per minutes for 5 minutes. (Ogbu et, al. 2015) PCV was read using Hawksley Microhaematocrit reader.

\section{Blood Films}

Separate glass slide were used in making the thick and thin blood films. In preparing thin blood film. A drop of blood about the size of pin head was taken on grease -free clean glass slide to about $2 \mathrm{~cm}$ from the right end. Second slide a spreader was used with the edge touching the drops of blood, the blood were allowed to run along the edge of the spreader slide. Pushing the spreader at an angle of 30 degree gently, evenly and quickly till the blood was exhausted. As the blood exhausted the film begins to form tails which end near about the centre of the glass slide, the films were allowed to air-dried (Arora, 2008). Precautions were taken to ensure equal volume of blood was used in each sample.

Thick blood films were made from larger volume of blood than thin blood film to increase the chance and speed of finding parasite (Cheesbrough, 2009). About 2-3 small drops of blood were taken near the centre on a slide. These were rapidly and evenly spread in to an area about $2 \mathrm{~cm}$ using a corner of another slide. The blood was continuously stirred for about 30seconds to prevent formation of fibrin cloth. The thicknesses of the film were such to allowed new-print to be seen or the hands of a wrist-watch to be seen through the dry preparation (Cheesbrough, 2009).

\section{Staining of Blood Films}

Giemsa staining technique was used for staining both thick and thin blood smears. A stained with $1: 10$ dilution of Giemsa stain in buffered water for 30 munites were used for staining the slide preparations. Although the stock solution of Giemsa stain were methanolic, the working solution were aqueous, hence thin blood films were fixed before they are stained to avoid lysing of red blood cells or creating artefacts.

\section{Microscopy of Blood Films}

Both thick and thin films were examined microscopically using $x 40$ and $x 100$ objectives. When examining the stained preparations, the condenser was raised to focus light on the specimen, and illumination adjusted to reveal colours of specimen optimally, it is important to examine the right 'part' and to find it quickly. The right area can be located with low power objective (x40).

Generally the oil immersion (x100) objective was used in both stained preparations to detect and confirm the identity of malaria parasites (Arora, 2008).

The following plus $(+)$ sign scheme was used to report the degree of parasitaemia: $(+)$ for low parasitaemia (1-10 parasites per 100 high power fields), $(++)$ for moderate parasitaemia (11- 100 parasites per 100 high power field) and $(+++)$ for severe parasitaemia (1-10 parasites in every high power field) (Cheesbrough, 2009).

\section{Identification of Malaria Parasites}

In stained preparations of thick and thin blood smears, malaria parasite species have different morphology so therefore varied in their appearance at different stages of development. Malaria parasite appears framed by the red cells in thin films. $P$. falciparum were the most widespread species that were found in the tropics often with high parasiteamia. Infected red cells appear normal in size and shape; multiple parasitized red cells were common. Only the trophozoite (Ring form) and gametocytes were usually seen, schizont are rare seen in peripheral blood, only occasionally seen in severe infection with 16-30 merozoites. The trophozoite lie on red cell membrane often with double chromatin dots, delicate, small ring, and scanty cytoplasm sometimes at the edge of the red cells. Gametocytes are cresent or banana shaped, but appears round forms if films that dry slowly. 
In thick film, the red cells were lysed, so their outlines were not usually apparent.

P.falciparum trophozoite often numerous delicate rings, all at the same stage of development. Rings turned to appear as exclaimation marks or propellers. Gametocytes were crescent shaped, may round up if the blood were taken several hours before films are made.

Parasite Density Estimation per Microlitre ( $\mu \mathrm{l})$ of Blood

The method of parasite enumeration was based on World Health Organisation (WHO) approved method. Using immersion oil objective (x100) systematically 200 white blood cells (WBC) were counted, estimating at the same time the number of parasites (asexual forms) in each field covered. The number of parasite per $\mu$ l of blood was calculated as follows; parasite count multiple by $8000 \mu$ l (assumed WBCs count by WHO) divided by set range of WBC (Sugiarto et al., 2008)

\section{Data Analysis}

Data collected were cleaned and entry was done using SPSS version 20.0.Chi square test was used to test for significant of association and a P-value of $=0.05$ was considered statistically significant.

\section{RESULTS}

The total positive sample recorded were 162 (35.7\%). The highest occurrence $47.4 \%$ was observed within 9-13 age group and the least $1.8 \%$ was found within 24-28 age grouped in Gwale. Statistically no significant difference ( $P$-value $>0.05$ ) was observed among the various age groups of the two local governments.

Table 1: Occurrence of malaria Parasitaemia by age among Almajirai in selected Traditional Qur'anic centres of Municipal and Gwale Local Government Areas of Kano state

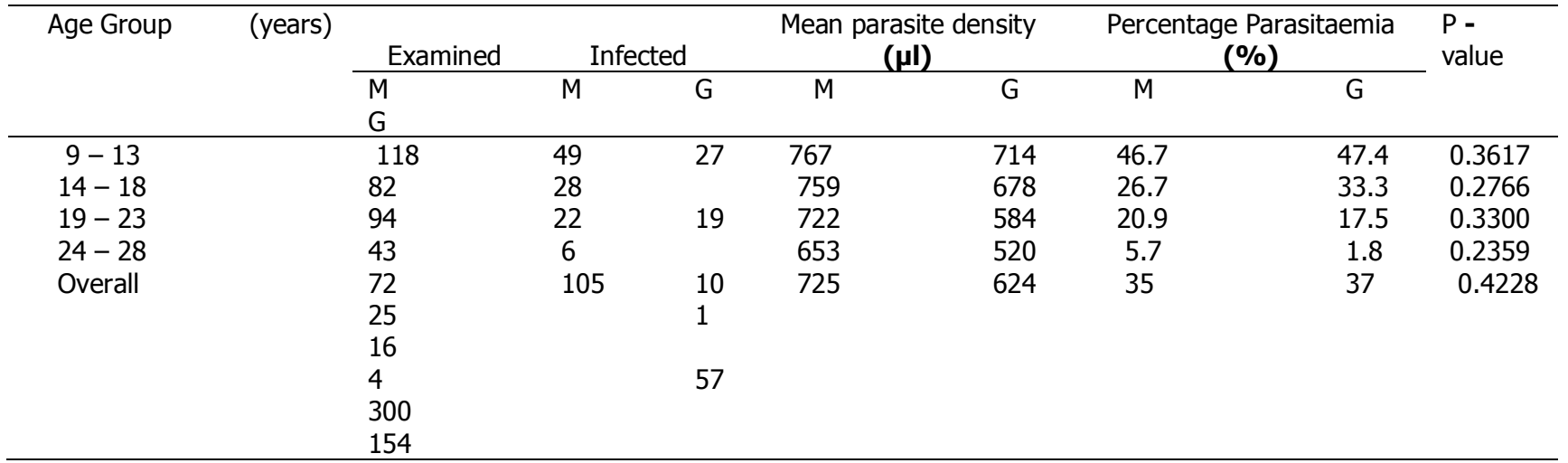

Key:

$\mu \mathrm{l}=$ Micro litre

$\%=$ Percentage

$M=$ Municipal LGA

$\mathrm{G}=$ Gwale LGA

Occurrences of malaria Parasitaemia by age among Almajirai in some selected traditional Qur'anic centres of Kano Municipal and Gwale Local Government Areas of Kano State is presented in Table 1 . Total positive sample recorded were 105 (35\%) and 57 (37\%) from Kano Municipal and Gwale respectively. Statistically no
Significant difference ( $P$-value $>0.05$ ) was found between the two local government areas for all age group's but rate of occurrence varied significant between age groups with highest rates $(47.4 \%)$ occurring in the 9-13 age group and the least in 24-28 age group (1.8\%).

Table 2: Intensity of malaria Parasitaemia ( $\mathrm{mp}$ ) in different age groups of Almajirai in selected Traditional Qur'anic centres of Municipal and Gwale Local Government Areas of Kano state

\begin{tabular}{|c|c|c|c|c|c|c|c|c|c|}
\hline \multirow{3}{*}{$\begin{array}{l}\text { Age } \\
\text { group } \\
\text { (years) } \\
9-13\end{array}$} & \multicolumn{3}{|c|}{ MUNICIPAL } & \multicolumn{2}{|c|}{ GWALE } & \multicolumn{3}{|c|}{ Mp-ve } & \multirow[t]{2}{*}{ P-value } \\
\hline & $\begin{array}{l}\mathrm{L}+ \\
(\%)\end{array}$ & $\begin{array}{c}M++ \\
(\%)\end{array}$ & $\begin{array}{c}\mathrm{S}+++ \\
(\%)\end{array}$ & $L+(\%)$ & $\begin{array}{c}\text { M++ } \\
(\%)\end{array}$ & $\begin{array}{c}\mathrm{S}+++ \\
(\%)\end{array}$ & $M$ & G & \\
\hline & $10(28.6)$ & $27(50)$ & $12(75)$ & $6(28.6)$ & $17(54.8)$ & $4(80)$ & $69(35.4)$ & $55(56.7)$ & 0.0270 \\
\hline $14-18$ & $14(40)$ & $13(24.1)$ & $1(6.3)$ & $8(38.1)$ & $10(32.3)$ & $1(20)$ & $66(33.8)$ & $24(24.7)$ & 0.6057 \\
\hline $19-23$ & $9(25.7)$ & $10(18.5)$ & $3(18.8)$ & $6(28.6)$ & $4(12.9)$ & & $50(25.6)$ & 15 (15.5) & 0.7078 \\
\hline $24-28$ & $2(5.7)$ & $4(7.4)$ & & $1(4.8)$ & & & $10(5.1)$ & $3(3.1)$ & 0.7945 \\
\hline Total & 35 & 54 & 16 & 21 & 31 & 5 & 195 & 97 & \\
\hline
\end{tabular}

Key:

$\mathrm{Mp}-\mathrm{ve}=$ Malaria Parasitaemia negative

$\mathrm{L}(+)=$ Low Parasitaemia

$\mathrm{M}(++)=$ Medium Parasitaemia

$\mathrm{S}(+++)=$ Severe Parasitaemia

$\%=$ Percentage

$M=$ Municipal Local Government

$\mathrm{G}=$ Gwale Local Government 
The distribution of malaria Parasitaemia per high field in stained blood preparations is shown in Table 2. The intensity of malaria Parasitaemia varied considerably between age groups. The highest intensity recorded $80 \%$ (severe malaria Parasitaemia) was in the $9-13$ age group and the least intensity recorded $4.8 \%$ (low

Table 3: occurrence of Anemia among Almajirai in some selected Traditional Qur'an cen observed P-value $<0.05$ between subjects in the 9-13age group for the two local governments, while for the remaining age groups no significant difference P-value > 0.05 was found.

\begin{tabular}{|c|c|c|c|c|c|c|c|c|c|c|c|c|c|c|c|c|c|c|c|c|}
\hline \multirow[b]{3}{*}{$\begin{array}{l}\text { Level of } \\
\text { Anemia }\end{array}$} & \multicolumn{4}{|c|}{$9-13$ years } & \multicolumn{3}{|c|}{$14-18$ years } & \multicolumn{4}{|c|}{$19-23$ years } & \multicolumn{4}{|c|}{$24-28$ years } & \multicolumn{4}{|c|}{ TOTAL } & \multirow{3}{*}{ P-value } \\
\hline & \multicolumn{2}{|c|}{ Mp+ve } & \multicolumn{2}{|c|}{ Mp-ve } & \multicolumn{2}{|c|}{ Mp+ve } & Mp-ve & \multicolumn{2}{|c|}{$M p+v e$} & \multicolumn{2}{|c|}{ Mp-ve } & \multicolumn{2}{|c|}{ Mp+ve } & \multicolumn{2}{|c|}{ Mp-ve } & \multicolumn{2}{|c|}{ Mp+ve } & \multicolumn{2}{|c|}{ Mp-ve } & \\
\hline & $M$ & $\mathrm{G}$ & $M$ & $\mathrm{G}$ & $M$ & G & $M \quad G$ & $M$ & G & $M$ & G & $M$ & G & $M$ & G & $M$ & G & M & G & \\
\hline Mild & 19 & 24 & 28 & 1 & 4 & 1 & 19 & 3 & - & 5 & - & - & - & 5 & & 26 & 25 & 57 & 1 & 0.0192 \\
\hline Severe & 8 & - & 9 & - & - & & & 1 & - & - & - & - & - & - & - & 11 & - & 13 & & \\
\hline Not Anemic & 22 & $\overline{3}$ & 32 & $\overline{54}$ & $\begin{array}{l}\overline{2} \\
22\end{array}$ & $\overline{18}$ & ${ }_{43}-$ & 18 & $\overline{10}$ & $\overline{45}$ & $\overline{15}$ & 6 & $\overline{1}$ & $\overline{5}$ & 3 & 68 & $\overline{32}$ & 125 & $\overline{96}$ & 0.0004 \\
\hline & & & & & 24 & & & & & & & & & & & & & & & 0.0308 \\
\hline
\end{tabular}

Key:

Mp -ve = Malaria Parasitaemia Negative

$\mathrm{Mp}+\mathrm{ve}=$ Malaria Parasitaemia Positive

$M=$ Municipal L.G.A

$\mathrm{G}=$ Gwale L.G.A

Occurrence of anaemia among A/majirai of different age group in some selected traditional Qur'anic centres is presented in Table 3. Anaemia (PCV $<33 \%$ mild and PCV $<25 \%$ severe anaemia) was compared between malaria parasitized subjects and non-parasitized subjects. Total of 51 and 11 subjects were recorded to have mild and severe anaemia respectively among malaria parasitized subjects and total of 58 and 13 subjects were recorded to have mild and severe anaemia respectively among non-parasitized subjects. Statistically Significant difference P-value $<0.05$ was observed between different age groups of the two local governments.

\section{Discussion}

The total positive samples recorded were $35.7 \%$, highest occurrences recorded were $47.4 \%$ within $9-13$ age groups and the least $1.8 \%$ recorded within $24-28$ age groups. The result obtained from this study might be because both the study sites have common characteristics within the metropolis, same climatic conditions as well as environmental features. Other reason may be due to the fact that the research was conducted during rainy season. Findings in this present study were in lined with previous studies from Kano State, Gobir and Tukur, (2014) who reported 30.59\%;

Bawa et al. (2014) observed 36.5\%. In contrast other previous result reported low prevalence's $19.3 \%$ reported by Ladi et al. (2015) from Makarfi.

Estimation of the intensity of Parasitaemia in peripheral blood is essential as $P$. falciparum infection may cause fatal illness and hyperparasitaemia is a criterion for the WHO's definition of severe malaria (WHO, 2006). This may be due to lack of personal engagement of the Almajirai to fight malaria, Tsangaya structure which exposes the respondent to the mosquitoes. These findings were in consistent with previous reports Bawa et. al, 2014; and Daboer et. al, 2015; In contrast findings were not in lined with the results of Clarke et. al, 2003, in Gambia where ITNs utilization was found to be a routine in most households with low malaria incidence; Anaemia was observed as common haematological changes in malaria $P$. falciparum infection. This was consistent with previous studies. This could be attributed to different preference of the malaria parasite attack to erythrocyte of all ages. Results in the present study were in lined with a study by Jain, 2007, who showed that $P$. falciparum infection induced anaemia; Agravat and Dhruva, 2010, reports that 93\% cases of anaemia were reported during $P$. falciparum infection. In contrast to the findings, study in Kenya among school aged children shown $80 \%$ anaemia due to iron deficiency (WHO/UNU/UNICEF, 2001). 


\section{Conclusion}

Finding in the present study indicated high Occurrence $35.7 \%$ and $P$. falciparum was the only species encountered during the study. Municipal Local Government Area have 35\% occurrence and Gwale Local Government Area have $37.0 \%$. Statistically no significant difference (P-value $>0.05$ ) was observed among the various age groups of the two local governments. Malaria Parasitaemia was observed to be associated with the intensity of malaria transmission. Anaemia was also observed as common haematological changes in malaria $P$. falciparum infection.

\section{Recommendation}

There is need to introduce appropriate intervention strategies against malaria and its vector. Community

\section{REFERENCES}

Agboola, T. F., Ajayi, B.M., Adeleke, M.A. and Gyang, P.V. (2010). Prevalence of malaria parasite among blood donors in Lagos, University Teaching Hospital, Lagos Nigeria. Annals of biology research, 1(3):72-75 (http://schorlashipreseachlibrary.com/archive .html)

Arora, D.R. (2008). Medical Parasitology. $2^{\text {nd }}$ edition published by satish kumar jain for CBS publishers and distributors, new Delhi India.

Bashir, S. G. (2014). Reforms for the promotion and development of Tsangaya School in the context of the Nigerian Educational System. Held at Centre for Qur'anic studies Bayero University Kano. A revised version of an earlier paper presented by the same author at an international conference in Malaysia.

Bawa, J.A., Auta, T. and Liadi, S. (2014). Prevalence Of Malaria: Knowledge, Attitude, And Practices Of Pregnant Women In Katsina Metropolis, Nigeria. European Scientific Journalvolume 10, No. 21.

CDC (Centre For Disease Control and Prevention) (2015). $\quad$ www.cdc.gov/malaria/ worldwide/impact [accessed on $16^{\text {th }}$ march 2016]

Clarke, S., Rouhani, S. and Diarra, S.(2013). The impact of intermitted parasite clearance on malaria, anaemia, and cogniyion in school children: new evidence from an area of highly seasonal transmission. Tropical Medicine and International Health $\mathbf{1 8}$ (suppl.1),64.

Erhabor, O., Mohammad, H.J., Onuigue, F.U., Abdulrahman, Y. and Ezimah, A.C. (2014). Anaemia And Thrombocytopenia Among Malaria Parasitized Children In Sokoto, North Western Nigeria. Journal of hematology and blood transfusion 2(2): 1020

Fadlullah, M. H. (2003). Islam the Religion of Dialogue, Dar al-mahadi, Beirut.

George, I. Ogbu, Chris O. Aimakhu, Stephen Ajen. Anzaku, Stephen Ngwam and Diane, A. Ogbu. (2015). Prevalence of malaria mobilization and health education regarding the importance of using ITNs to prevent malaria and saves lives should be considered.

\section{Acknowledgements}

The authors acknowledge the efforts of Mal Umar Sani Dorayi and Mal Hassan Garko for their technical assistant, Mal Mahdi assistant analysist PG School and Mal Isa KUST Wudil for the statistical analysis.

\section{Contribution of Authors}

Hamma Amina Babayo write the manusript, Dr Zainab Tukur pro-read the manuscript and make corrections accordingly.

\section{Conflict of Interest}

The authors declare that there is no conflict of interest.

parasitaemia among asymptomatic women at booking visit in a tertiary hospital Northcentral, Nigeria. Journal of productive biology and health, volume 3(1)

Gregory, S., Noland, Patricia, M., Graves1, Adamu Sallau, Abel Eigege, Emmanuel, Emukah, Amy, E., Patterson, Joseph, Ajiji, Iheanyichi Okorofor, Oji, Uka. Oji, Mary Umar, Kal Alphonsus, James Damen, Jeremiah, Ngondi., Masayo Ozaki, Elizabeth Cromwel, Josephine Obiezu, Solomon Eneiramo, Chinyere Okoro, Renn. McClintic-Doyle, Olusola Oresanya, Emmanuel Miri, Paul, M., Emerson, and Frank, O. and Richards Jr. (2014). Malaria prevalence, anemia and baseline intervention coverage prior to mass net distributions in Abia and Plateau States, Nigeria. Research Article Biomed Central infectious disease 14:168.

Ifeanyichukwu, M.O. and Esan, A.J. (2014). Evaluation of haemoglobin concentration, packed cell volume and red cell indices in pre-and post-anti-malaria drug treatment in plasmodium falciparum malaria infection and control individual. Global advance research journal of Microbiology. Volume 3(2) pp. 012-017.

Imam T.S.(2009). Anaemia and malaria in Children attending two Selected Paediatric Clinics in Kano Metropolis, Northern Nigeria. International Journal of Biomedical and Health Sciences. Vol.5, No. 3

Irene, U.N. Sumbele., Teh. R. Ning, Orelien, S.M.Bopda., and Theresa, Nkuo-Akenji. (2014). Variation in malariometric and red indices in children in the Mount Cameroon area following malaria enhanced control measures: evidence from a repeated crosssectional study. Malaria journal 13(1)334.

Jumbo, Gta., Mbaawuaga, E.M., Anongu st, Egah, D.Z., Enenebea, K.U. Mno., Peter, E.J.Utsalosji, Okwori, Ee. and Odey, F. (2010). The burden of malaria among under five children: Finding from Makurdi city, Northcentral Nigeria. Review in Infection. 1(3): 140-144. 
Kelani Omotoso Ajadi, Hezekiah D. Olaniran, Folami Munta Alabi and David O. Adejumobi. (2012). Incidence of malaria among various rural socio-economic households. Greener Journal of Medical Science. Volume 2 (3), pp.051-063.

Lethen, G. J. and Tomlinson, C. J. F. (1927). History of Islamic Political Propaganda in Nigeria, Volumes. 1 and II, waterloo and sons Limited, London.

Monica cheesbrough, (2009). District Laboratory Practice in Tropical Countries, second edition updated part 1,Cambridge University Press, New York. 245-254pp.

Muhammed,R.H., Hamisu, B.A., and Binta, B.M. (2011). Knowledge, Attitude, And Practice On Malaria In Kano Metropolis. World Journal of Life Science and Medical Research. 1 (4):83-87
Okafor, I.M., Mbah, M. and Usanga, E.A. (2012). The impact of anaemia and malaria parasite infection in pregnant women. Nigerian Perspective. Journal of Dental and Medical Sciences. Volume1, pp 34-38.

Oyeyi T.I, Muhammed Ruqayya Hamidu, and Muhammed Ado Dakata (2009). Slide positivity rate of malaria among patients attending two hospitals in Kano metropolis. Bayero Journal of Pure and Applied Sciences, 2(2):194-196

Sunusi, Iguda K., Nasarawa. (2005). Tsangaya Education in Focus. A publication of the Office of the special adviser on education and information technology, Kano State.

Gobir, Z and Tukur, Z. (2014).Prevalence of malaria Parasitaemia using rapid diagnostic test among apparently healthy children in Kano, Nigeria. Journal of Medicine in the Tropics Vol 16: 1:1-4 